\title{
Policy Integration and Coherence for Conservation Agriculture Initiatives in Malawi
}

\author{
Edna L. Chinseu ${ }^{1}$, Lindsay C. Stringer ${ }^{1} \&$ Andrew J. Dougill ${ }^{1}$ \\ ${ }^{1}$ Sustainability Research Institute, School of Earth and Environment, University of Leeds, Leeds LS2 9JT, United \\ Kingdom
}

Correspondence: Edna L. Chinseu, Sustainability Research Institute, School of Earth and Environment, University of Leeds, Leeds LS2 9JT, United Kingdom. E-mail: eeelc@leeds.ac.uk

Received: June 27, 2018 Accepted: July 13, 2018 Online Published: August 9, 2018

doi:10.5539/sar.v7n4p51 URL: https://doi.org/10.5539/sar.v7n4p51

\begin{abstract}
In sub-Saharan Africa, development and dissemination of perceived new agricultural innovations dominate the development agenda yet hunger and poverty remain widespread. A conducive policy environment is essential to support these efforts. Despite that national policies are a critical component in the functioning of an agricultural innovation system, studies have often overlooked their relevance in farmers' adoption of agricultural innovations. There is an urgent need to enhance understanding of how policies affect long-term adoption of agricultural innovations aimed at increasing productivity and incomes of smallholder farmers. This study utilises thematic content analysis to examine the extent of integration of Conservation Agriculture (CA) and coherence in Malawi's national agricultural policies, and their implication for CA adoption among smallholder farmers.

Results indicate that inadequate integration of CA in the National Agricultural Policy (NAP), coupled with a lack of coherence of agricultural department policies, undermines farmers' CA adoption. While inadequate integration constrains resource allocation for supporting CA activities, lack of coherence of agricultural policies radiates conflicting and confusing agricultural extension messages to smallholder farmers. We argue that inadequate CA integration and incoherence of policies are institutional constraints which prevent farmers' sustained adoption. To facilitate long-term adoption of CA among smallholders, there is need to: (1) strengthen CA integration in agricultural policies; (2) improve departmental coordination to enhance coherence of agricultural strategies and extension messages disseminated to farmers; and (3) strengthen government's role in supporting multi-disciplinary research to generate and disseminate best practices capable of sustaining CA adoption.
\end{abstract}

Keywords: climate smart agriculture, governance, institutional analysis, policy interplay, sub-Saharan Africa, sustainability

\section{Background}

Hunger and poverty are pressing concerns of development agents and national governments worldwide. A report issued by the United Nations Food and Agriculture Organisation estimates that 815 million people are currently experiencing hunger globally (Food and Agriculture Organisation [FAO], 2017), despite agriculture being a key economic sector and main source of employment in many countries (Lipper et al., 2014). Generation and dissemination of new agricultural innovations has traditionally driven the national development and policy agenda in the sub-Saharan region (Teklewold, Kassie, \& Shiferaw, 2012) as attempts have continued to address these concerns. One such innovation is conservation agriculture (CA), defined as a sustainable farming system anchored on three fundamental principles: minimal soil disturbance (reduced tillage), permanent soil cover and crop associations (Kaluzi, Thierfelder, \& Hopkins, 2017). According to FAO (2015), the three principles need to be practised simultaneously, in addition to other good agricultural practices, for optimal results. CA is widely advocated as a promising technology for improving agricultural productivity, food security, sustainable land management, and smallholder farmers' resilience to climate change impacts (FAO, 2018).

While current innovation systems approaches suggest that policies are an important component in the functioning of an innovation system (Hall, Mytelka, \& Oyeyinka, 2006; Spielman \& Birner, 2008), farming systems studies often overlook policies (Feder, Just, \& Zilberman, 1985; Doss, 2006); hence empirical evidence of linkages between policies and challenges in sustaining adoption of agricultural innovations is lacking. Despite that policies are central in guiding national priorities (Kalaba, Quinn, \& Dougill, 2014), their role in shaping the 
context in which smallholder farmers operate and adopt innovations remains poorly understood. It is thus imperative to generate in-depth understanding of how national policies shape smallholders' adoption of agricultural development interventions, where livelihoods largely depend on agriculture.

The aim of this article is to analyse the role of national policies in smallholder farmers' adoption of CA in Malawi. The paper focuses on analysis of policy documents from across the Ministry of Agriculture, Irrigation and Water Development [MoAIWD], which has the mandate to implement all agriculture related activities in the country. Specific objectives are: (1) to analyse the extent of integration of CA in the relevant policy documents of the MoAIWD; (2) to analyse coherence of departmental strategies and guidelines for CA implementation; and (3) to examine implications of policy integration and coherence for smallholders' adoption of CA.

\subsection{Theoretical Framework}

Policy integration refers to the extent to which a social, economic or environmental objective or consideration is embedded into (national) policy (Oberthur, 2009). Research on policy integration has mostly been devoted to assessing the extent of integration of international agreements into national policies (Stringer et al., 2009; Nilsson et al., 2012; England, Stringer, Dougill, \& Afionis, 2018; Atela, Quinn, Minang, Duguma, \& Houdet, 2016), while globally, integration of sectoral and departmental policies remains a common challenge (Oberthur, 2009). There is a critical lack of knowledge on the integration of agricultural considerations and issues at sectoral/sub-sectoral levels (Gomar, Stringer, \& Paavola, 2014). Analysing integration of policies at lower governance levels is important to understand how policies at national level can affect adoption of agricultural interventions at the grassroots, since this is where policy intent translates into action.

Policy coherence relates to how two or more policies and/or their implementation arrangements interact in achieving their objectives (May, Sapotichne, \& Workman, 2006). The effectiveness of policies (e.g. at national, sectoral or departmental level) may be either reinforced or undermined by other policies, producing either mutually-supporting or adverse outcomes (Dixon \& Stringer, 2015; Lasco, Cruz, R. Pulhin, \& J. Puhlin 2006; Soderberg, 2008). Coherence has become a crucial variable in policy analysis considering its importance in determining policy effectiveness (Atela et al., 2016). As national implementation arrangements often involve multiple sectors and stakeholders (Chandra \& Idrisova, 2011), outcomes of one policy (e.g. sustainable food production) are often a sum of all decisions, policies and actions from more than one government agency (Glasbergen, 1996). However, research into coherence has mostly focussed on examining policies at ministerial governance levels (e.g. Kalaba et al., 2014; Atela et al., 2016) with little scholarly attention focusing on sub-sectoral/departmental policies at lower governance levels. Exploring coherence is necessary to identify where policy statements or actions in different departments are supporting or conflicting with each other in the context of CA, particularly given that CA is a multi-sectoral technology (Chinsinga \& Chasukwa, 2015).

Cejudo and Michel (2017) argue that policy integration, and coherence are interrelated; such that poor integration, often emanating from poor coordination, culminates in incoherent policies. Similarly, Soderberg (2008), Stringer et al. (2012) and Kalaba et al. (2014) observed that different government sectors or agencies tend to work in isolation, and may produce antagonistic relationships which do not facilitate joint problem solving. When departments work independently, there is a lack of joint learning and long-term alignment of over-arching objectives across departments, resulting in contradictory messages and wastage of resources (England et al., 2018). Coherence in policies can be undermined when interests and policy issues pull in different directions, or they can be reinforced when they are in harmony (May et al., 2006). Stringer et al. (2009) noted that in Southern Africa, mutually supportive links between policy strategies are often poorly developed; such that even if overlaps exist, opportunities usually remain unexploited. For Malawian agriculture, Dougill et al. (2017) contend that multilevel institutional inefficiencies, policy conflicts and gaps limit the effectiveness of CA and sustainable land management agenda. Considering that policy integration and coherence are interlinked (Cejudo \& Michel, 2017), simultaneous examination of integration and coherence of policies is necessary to generate insights to improve the policy environment in which smallholder farmers adopt and/or implement agricultural development interventions.

\section{Research Design and Methods}

\subsection{Case Study}

Malawi provided an appropriate case for this study because despite CA being incorporated in Malawi's agricultural policies, as a strategy for improving agricultural production and resilience in smallholder farming systems (Mloza-Banda \& Nanthambwe, 2010), adoption levels remain meagre with only 2\% of the country's smallholders practicing some form of CA (Kaluzi et al., 2017). This signals potential shortcomings in relevant policies vis-a-vis CA, considering that policies shape what gets prioritised and implemented. Additionally, 
organisational complexity of the Ministry of Agriculture, Irrigation and Water Development and its policy mechanisms (Chinsinga \& Chasukwa, 2015) necessitate a better understanding of the agricultural policy environment. Improving the policy context for CA is important for Malawi's predominantly agrarian economy, with over $80 \%$ of the population relying on rain fed agriculture for their livelihoods (Malawi Government, 2016).

\subsection{Methods and Data Analysis}

Purposive sampling was used to select documentary materials for in-depth analysis, since what matters most in the choice and sample size of text for document analysis is the "richness of textual detail" (Waitt, 2010, pp 222), and its usefulness and relevance to the research objectives (Baxter \& Eyles, 1997). The documents analysed were Malawi government sectoral policies as published by the different Departments across the Ministry of Agriculture, Irrigation and Water Development. To ensure document authenticity (Scott, 1990), selected policy documents were physically obtained from the relevant Ministry headquarters (Table 1).

Table 1. Description of Malawi national policy documents analysed

\begin{tabular}{|c|c|c|c|}
\hline Policy document & Responsible sector & Description & $\begin{array}{l}\text { Analysis } \\
\text { focus }\end{array}$ \\
\hline National Agriculture Policy (NAP) & MoAIWD & $\begin{array}{l}\text { National policy on agriculture (Malawi } \\
\text { Government, 2016) }\end{array}$ & integration \\
\hline $\begin{array}{l}\text { Agriculture Sector-wide Approach } \\
\text { (ASWAp) (under review) }\end{array}$ & MoAIWD & $\begin{array}{l}\text { Programme-based agriculture investment plan } \\
\text { outlining the national agriculture development } \\
\text { agenda (Malawi Government, 2010) }\end{array}$ & integration \\
\hline $\begin{array}{l}\text { Guide to Agricultural Production and } \\
\text { Natural Resources Management in } \\
\text { Malawi (GAPNRM) }\end{array}$ & $\begin{array}{l}\text { MoAIWD (all Departments } \\
\text { in the Ministry) }\end{array}$ & $\begin{array}{l}\text { Departmental guidelines on good agriculture } \\
\text { practices in Malawi (Malawi Government, 2012) }\end{array}$ & coherence \\
\hline $\begin{array}{l}\text { Guideline for implementation of } \\
\text { conservation agriculture in Malawi }\end{array}$ & $\begin{array}{l}\text { MoAIWD (Department of } \\
\text { Land Resources and } \\
\text { Conservation) }\end{array}$ & $\begin{array}{lccc}\text { Malawi national conservation } & \text { agriculture } \\
\text { guidelines } & \text { (National } & \text { Conservation } & \text { Agriculture } \\
\text { Task Force } & [\mathrm{NCATF}], 2016) & \\
\end{array}$ & coherence \\
\hline
\end{tabular}

Note. MoAIWD= Ministry of Agriculture, Irrigation and Water Development.

Policy documents were analysed using thematic content analysis (Bryman, 2016), which is a commonly used method for analysing textual data (Hay, 2010). Analysis of CA integration entailed systematically examining dominant narratives in the policy documents to establish the presence, prominence and context in which CA appears in the text. Criteria for assessing the extent of CA integration into policy documents were adapted from Mwase et al. (2014) (Table 2).

Table 2. CA integration assessment criteria adapted from Mwase et al. (2014)

\begin{tabular}{ll}
\hline Rating & Description \\
\hline Very weak & CA completely absent in the policy document \\
Weak & The policy does not explicitly mention CA but some aspects related to CA are specified \\
Moderate & CA explicitly specified only in policy strategies and/or implementation plan \\
Strong & CA explicitly specified in policy objectives, strategies and monitoring and evaluation framework \\
Very strong & CA explicitly specified in policy objectives, strategies, monitoring and evaluation framework and funding mechanism \\
\hline
\end{tabular}

Policy coherence was analysed through the perspective of policy interaction (Nilsson et al., 2012; Young, 2002). This entailed analysing implementation strategies derived from the Guide to Agricultural Production and Natural Resources Management, which contains the 'how-to' technical knowledge from all Departments in the MoAIWD and is the reference manual for agricultural extension officers (Malawi Government, 2012). Interactions between the strategies were examined to determine their relationship with CA adoption. This entailed first compiling an inventory of strategies, from which a screening matrix (Soderberg, 2008) was developed. The next step was to isolate strategies relevant to CA, and to examine key interactions. Coherence with CA adoption was illustrated using criteria adapted from Nilsson et al. (2012) and Oberthur and Gehring (2006) denoted as: (1) positive - where Departmental activities support CA adoption (2) negative - where activities undermine or conflict with CA adoption or (3) neutral - where no clear effect on CA adoption was established. Data on key outcomes was displayed qualitatively to elucidate whether or not the policy implementation arrangements were mutually reinforcing, impeding or contradicting adoption of CA in Malawi. 


\section{Results}

\subsection{Extent of CA Integration in National Agriculture Policy (NAP) and Agriculture Sector-wide Approach (ASWAP)}

Although the NAP is the key policy document for agricultural development in Malawi, CA integration is moderate; it only appears at the lower level of the policy, in implementation plans, under "promoting investments in climate smart agriculture and sustainable land and water management including integrated soil fertility management and conservation and utilisation of Malawi's rich agrobiodiversity" (Malawi Government, 2016). Similarly, integration of CA in the ASWAp policy document is moderate. Absence of CA in broader policy statements (goals, objectives and priority areas) demonstrates that CA is insufficiently embeded as a priority national strategy for achieving agricultural goals and objectives. This suggests that CA lacks political recognition and support at the national governance level. Considering that no funding mechanisms are outlined in the NAP, availability of finances and other resources for implementing CA activities on the ground is uncertain.

Results show that failure to embrace CA more broadly underlies insufficient integration of CA in the agricultural policy documents, and is manifested by CA gaps and/or missed opportunities in relevant thematic policy areas (Table 3).

Table 3. CA missed opportunities and gaps in key thematic policy areas

\begin{tabular}{llr}
\cline { 2 - 3 } Key thematic policy area & \multicolumn{2}{c}{ Policy } \\
\cline { 2 - 4 } & FAP & ASWAP \\
\hline Agricultural risk management & $\mathrm{X}$ & $\mathrm{X}$ \\
Catchment restoration and conservation & $\mathrm{X}$ & $\mathrm{X}$ \\
Irrigation and rainwater harvesting & $\mathrm{X}$ & $\mathrm{X}$ \\
Research and technology transfer & $\mathrm{X}$ & $\mathrm{X}$ \\
Soil health & $\mathrm{O}$ & $\mathrm{O}$ \\
\hline
\end{tabular}

Note. $\mathrm{x}=$ gap identified; $\mathrm{o}=$ no gap identified.

The food security policy area of the NAP emphasises use of inorganic fertilisers, improved crop varieties, herbicides and pesticides. As a result, national priorities and resources have been biased towards these strategies (Chinsinga, 2011), at the expense of sustainable land and water management (SLWM) which includes CA. Considering that SLWM strategies are pre-requisite to any sustainable agricultural production system (Mwase et al., 2014), there is a case for stronger CA integration in agricultural policies. The current NAP was launched in 2016 with the overall goal "to achieve sustainable agricultural transformation that will result in significant growth of the agriculture sector, increased incomes for farming households, improved food and nutrition security for all Malawians and increased agricultural exports" (Malawi Government, 2016). CA has potential to improve yields especially in areas with sandy soils (Steward et al., 2018) and contribute to food security (FAO, 2018; Thierfelder et al., 2016). However, failure to recognise broader potential of CA undermines its incorporation in strategies for achieving food security goals in Malawi's agricultural policies.

Findings show that CA is mainly included in the NAP and ASWAP as a farm-level intervention under rain-fed agriculture, hence a gap exists under the policy thematic area of irrigation and rain water harvesting (Table 4). While the ASWAP articulates its purpose to: "increase soil water and nutrient buffer capacity to ensure higher productivity of rain-fed crops" (Malawi Government, 2010), the policy noticeably overlooks application of CA in irrigation farming. Similarly, the NAP overlooks CA in the sustainable irrigation development priority area; yet application of CA practices has potential to reduce problems of siltation of rivers/streams, reduced river flows, and moisture stress in crops constantly reported as major challenges in most irrigation schemes in Malawi (Department of Irrigation Services, 2015). Since implementation of CA principles of permanent soil cover and minimum soil disturbance improves water infiltration and water holding capacity of soil while reducing surface runoff and soil erosion (Njira \& Nabwami, 2013), there is scope for stronger CA integration in sustainable irrigation development and catchment restoration and conservation thematic areas of NAP and ASWAp.

Though development partners such as FAO and other donors regard CA as an adaptation strategy to prolonged dry spells, CA is conspicuously missing in the NAP's agricultural risk management priority area, and ASWAp's climate change sub-component. For managing agricultural risk, the two policies have prioritised strategies such as: increasing adoption of drought tolerant crop varieties; promoting weather-index crop and livestock insurance and early warning systems; strengthening commodity exchange systems; and rainwater harvesting. Although CA is applicable for water harvesting strategies, it has not been explicitly included under the climate change 
sub-component. Lack of explicit mention of CA under the rainwater harvesting strategy practically excludes it from resources allocated for rainwater harvesting; in Malawi, rainwater harvesting is synonymous with construction of physical structures such as dams and underground or above-ground water tanks (Rainwater Harvesting Association of Malawi [RHAM], 2013). When used in conjunction with other agricultural risk-combating interventions, CA has the potential to capture and conserve rainfall in-situ, recharge ground water, thereby maintaining the water table within the root zone. Thus, CA may help prevent total crop failure especially in drought prone areas (NCATF, 2016; Thierfelder et al., 2016).

Despite the need to generate more knowledge due to challenges and controversies associated with CA (Kirkegaard et al., 2014; Andersson \& D'Souza, 2014; Glover, Sumberg, \& Andersson, 2016), CA is not specifically mentioned among the policy priority research areas of the NAP. Evidence in the literature shows that there is growing need for adaptive research aimed at enhancing the performance of, and contextualising of, CA to different agro-ecological and social contexts (Whitfield et al., 2015). Nevertheless, the NAP's research mainly focuses on developing new, high yielding, disease-resistant, and drought-tolerant crop varieties. Thus, a gap exists for incorporating CA in the agricultural research agenda, including adaptive research and performance evaluation of technologies already developed and disseminated to smallholder farmers to enhance understanding of interactions among technological, social, political and environmental factors in adoption and dis-adoption decision processes. This would enable researchers and practitioners to obtain valuable evidence required to customise technologies to local contexts, necessary for enhanced and sustained adoption of agricultural innovations among smallholder farmers.

While broader engagement of relevant stakeholders in the CA innovation system is essential, implementation arrangements of the NAP have overlooked the role of several key stakeholders. Only a few organisations have been mentioned as having a role in CA: the MoAIWD's three Departments of Land Resources and Conservation, Agricultural Extension Services and Agricultural Research Services, Non-Governmental Organisations (NGOs) and farmers' organisations. Other organisations and institutions have not been specifically included such as Departments of Crop Production, Animal Health and Livestock Development, Irrigation Services and Environmental Affairs; academic experts, International Agricultural Research institutions, Civil Society organisations (policy advocates) and the private sector (e.g. seed companies and agro-dealers). This questions the level of inclusiveness and involvement of stakeholders in the formulation of the policies. Excluding such important stakeholders is likely to lead to disjointed efforts in CA and raises the likelihood of both political and practical contradictions in policy, dissemination and/or agricultural extension, unfavourably affecting the operating environment of farmers. The following sections elucidate incoherencies in agricultural policies and their implication for CA.

\subsection{Incoherencies in Departmental Strategies of the MoAIWD}

Results of the analysis of coherence of departmental strategies of the MoAIWD unveiled both positive and negative interactions with CA (Table 4).

Table 4. Key interactions between MoAIWD Departmental strategies and CA

\begin{tabular}{|c|c|c|}
\hline Department & Strategy being promoted & Interaction with CA \\
\hline \multirow[t]{7}{*}{ DCP } & Tractor hire ploughs, ridgers \& cultivators & $-\mathrm{ve}$ \\
\hline & Oxen hire ploughs \& ridgers & -ve \\
\hline & Herbicides and pesticides & +ve/-ve \\
\hline & Chemical fertilisers \& hybrid seed & $+\mathrm{ve} /-\mathrm{ve}$ \\
\hline & Crop diversification & $+\mathrm{ve}$ \\
\hline & Sasakawa planting method & -ve \\
\hline & Deep ploughing \& ridges & -ve \\
\hline \multirow[t]{4}{*}{ DAHLD } & Crop residues for livestock feed & -ve \\
\hline & Improved pastures & $+\mathrm{ve}$ \\
\hline & Off-pasture grazing & -ve \\
\hline & Stall feeding & +ve/-ve \\
\hline \multirow[t]{9}{*}{ DLRC } & Planting ridges (tied/box ridges, ridge alignment contour ridging) & $-\mathrm{ve}$ \\
\hline & Crop residue incorporation & $-\mathrm{ve}$ \\
\hline & Minimum tillage & $+\mathrm{ve}$ \\
\hline & Cover crops \& mulching & $+\mathrm{ve}$ \\
\hline & Compost manure & $+\mathrm{ve} /-\mathrm{ve}$ \\
\hline & Agroforestry & $+\mathrm{ve}$ \\
\hline & Planting basins & +ve \\
\hline & Vetiver hedgerows & +ve/-ve \\
\hline & Herbicides & +ve/-ve \\
\hline DAES & Lead farmer approach & $+\mathrm{ve} /-\mathrm{ve}$ \\
\hline
\end{tabular}


Note. DCP $=$ Department of Crop Production; DAHLD $=$ Department of Animal Health and Livestock Development; DLRC $=$ Department of Land Resources and Conservation (host department for CA); DAES $=$ Department of Agricultural Extension Services; +ve $=$ positive interaction; $-\mathrm{ve}=$ negative and/or conflicting interaction

Table 4 illustrates that numerous strategies exist across key departments of the MoAIWD that are incoherent with CA due to their negative interaction with CA principles and/or social-economic aspects of CA adoption. In addition, some strategies though apparently positive, have the potential to exert negative impacts on CA if poorly designed and executed, thus carrying a risk of undermining CA promotion efforts and/or adoption.

Promotion of conventional tillage strategies by the DCP and DLRC (Table 4) stands in conflict with the minimum soil disturbance pillar of CA. One of the national priority areas, to facilitate agricultural development as stated in the NAP, is to intensify farm mechanisation hence the promotion of tractor and animal-drawn ploughs, ridgers and cultivators by the DCP, being the host department of tractor and oxen hire programmes (Malawi Government, 2016). Also, the DLRC is self-conflicting as it simultaneously promotes tillage practices such as contour, marker and tied/box ridges as soil and water conservation measures, and CA (Table 4). Ploughing and ridging involve turning the soil every season and have been the benchmark of agriculture policy since the colonial era (Nanthambwe \& Mulenga, 1999). While promotion of farm machinery is well intended to reduce the labour burden on farmers (Friedrich \& Kassam, 2009), exclusion of CA compatible equipment such as soil rippers and specialised planting equipment in the NAP mechanisation strategy, in addition to the department's promotion of conventional tillage practices, promulgate conflicting signals to extension agents and farmers, thereby undermining CA promotion efforts.

The DAHLD strategy of emphasising preservation of crop residues for livestock feed: "collect, stack crop residues and protect them by thorn bush barriers" (Malawi Government, 2012), constrains crop residue supply for CA farmers particularly in mixed crop-livestock systems. Although planting of vetiver grass is promoted for soil and water conservation purposes (Malawi Government, 2012), it is unsuitable for livestock feeding as compared to alternatives such as Rhodes grass (Chloris gayana) or Napier grass (Pennisetum purpureum) (Gondwe, 2015). Thus, emphasis on promoting vetiver grass by the DLRC intensifies conflicts over crop residues between livestock and CA. The DLRC also exacerbates competition for crop residues by promoting residue incorporation (to make compost $i n$-situ), limiting the availability of mulch materials and undermining CA's principle of continuous soil cover as farmers resort to applying very thin mulch (Chinseu, 2018). While compost manure is useful in improving soil health (Mereu et al., 2018), the strategy can reduce the availability of crop residues for CA mulching especially under smallholder farming conditions which typically produce insufficient biomass (Andersson \& D'Souza, 2014; Baudron, Andersson, Corbeels, \& Giller, 2011). Negative interactions of applying compost manure and crop residue mulch highlight the need to explore alternative strategies (such as liquid manure or cover crops) capable of minimising (unintended) negative consequences while enhancing CA synergistic interactions in the smallholder farming system.

While the sasakawa planting method is promoted by the DCP to optimise plant population and increase crop yield per unit area (Sasakawa Africa Association, 2007), the strategy contradicts the crop association pillar of CA, because it encourages maize monocropping. Locally known as the 'one-one' planting method (Malawi Government, 2012), the sasakawa method of planting sends conflicting signals to CA farmers who are simultaneously advised by the DLRC to adopt intercropping in CA systems. This suggests that coordination between the DCP and DLRC is deficient, hence the propagation of inconsistent and incoherent strategies. Under such circumstances, extension messages disseminated to farmers are conflicting as departments push their agendas without synchronising with each other's strategies. Similarly, incoherencies sowing confusion among smallholder farmers are also evident in Malawi's CA guidelines, shown in the next section.

\subsection{Incoherence of Malawi's CA Guidelines}

Although the CA guidelines are meant to "harmonise extension messages and minimise confusion and controversy over the definition and practice of CA in Malawi" (NCATF, 2016), inconsistencies and contradictions exist (Table 5). 
Table 5. Incoherencies, controversy and contradictions in Malawi's CA guidelines (NCATF, 2016)

\begin{tabular}{l} 
Extract from the CA manual \\
(NCATF, 2016) \\
\hline "CA produces higher and more stable yields \\
under variable rainfall" ( $\mathrm{p} 3$ ) \\
"Achieving the benefits of CA necessitates the \\
adoption of practices that require a break in \\
cultural norms such as ploughing, ridging and \\
keeping the fields completely clean" ( 3 3) \\
"Minimum soil disturbance is fundamental and \\
non-negotiable" 9
\end{tabular}

CA's effectiveness, simplicity and affordability without explicit needs for inputs and tools is a key feature to attract adoption" (p8)
Elucidation/Remarks

\author{
Yield increases under CA take time ( $>5$ years). This may raise false expectations \\ particularly among smallholder farmers who largely expect immediate benefits. \\ Inconsistent with other pronouncement in the same document stating that "one of the \\ attractive features of CA is... compatibility with common methods of planting” (p8)
}

\begin{abstract}
Minimum soil disturbance refers to no-till system. Inconsistent with document sentiments of the need for flexibility to adapt CA to local circumstances and farmer preferences: "adapt CA with farmer-specific circumstances" $\mathrm{p} 29$, and "adapting a technology to their specific needs and circumstances is crucial to attract interest in adoption" (p28)

Conflicts with another section of the same guidelines which has included inorganic fertilisers, hybrid varieties, herbicides, jab planters and soil rippers in "Malawi's system of $C A$ " (p9); these inputs are deemed expensive by smallholder farmers who also perceive CA to be complex
\end{abstract}

Although the NCATF guidelines acknowledge that " $C A$ is a soil and water conservation practice rather than a soil fertility practice per se" (p14), they simultaneously offer contradicting sentiments which seem to discourage the use of planting basins, the most appropriate in-situ water conservation practice for the Malawi context. While emphasising no-till systems, the guidelines have amplified negative aspects of planting basins while down-playing their benefits: "Digging planting basins involves significant soil disturbance and labour for digging"( $\mathrm{p}$ 15), and "In Malawi...the added value of water conservation in basins has not been established against the high labour cost of digging basins" (p55). Consequently, planting basins have been excluded from the frame of "Malawi's system of CA" (p9), yet the need to harvest rainwater in-situ is often a primary motivation for many CA farmers in Malawi, more importantly in the wake of frequent dry spells regularly experienced in Malawi in recent years and projected into the future (Sutcliffe, Dougill, \& Quinn, 2016). In addition, research needs identified in the CA manual have only specified economic and biophysical studies "to provide evidence of its [CA] performance" (p29), and have overlooked social-cultural and institutional analyses that can broaden understanding of farmers' adoption, up-scaling or dis-adoption decisions. Multidisciplinary analyses would be more useful in generating relevant knowledge to inform policy and aid modification and/or tailoring CA projects to farmers' unique conditions, necessary for achieving more sustained adoption/up-scaling of CA.

\section{Discussion}

Although CA is a dominant rhetoric in agricultural development arena in Malawi, its integration in national agricultural policies remains inadequate to support its effective uptake. Findings in this article reveal poor integration of CA in the country's dominant agricultural policies, despite stated intentions of promoting SLWM as a means of achieving sustainable agriculture production and resilient socio-economic development. Inadequate integration of CA in the NAP diminishes chances of CA benefiting from national priority funding; considering that Malawi government annual budgets are finalised at the national level at the Ministry headquarters, where national objectives and strategies get re-prioritised following numerous prioritisations at lower levels of government. Therefore, even though CA features at lower policy levels in implementation plans, poor allocation of human and financial resources is inevitable, and this undermines implementation of CA activities on the ground (Lasco et al., 2006). As argued by Kalaba et al. (2014), policy strategies and actions that are prioritised at national level stand a better chance of being implemented because sufficient financial as well as technical resources are allocated due to strong support at the top level of governance. Since CA support at the top governance level is weak, financial and human resources for carrying out CA activities feature as one of the commonly cited institutional constraints in CA implementation (Dougill et al., 2017).

Narrow perspectives on CA in the agricultural policy documents, where CA is mainly viewed as a farm level technology for rain-fed agricultural production, have restricted inclusion of CA in other relevant policy areas. The limited awareness of CA and its broader applicability in achieving broader agricultural policy objectives signifies weak collaboration among researchers, practitioners and policy makers within the CA innovation system. This has hindered broader integration of CA in key policies and undermined potential to demonstrate multi-functionality of CA, thereby diminishing its stature in the policy arena. Strengthening stakeholder collaboration within the CA innovation system and greater advocacy in policy are thus paramount in deepening CA awareness and integration (Dougill et al., 2017). 
Inadequate incorporation of $\mathrm{CA}$ in the government's research agenda of key policies has led to NGOs dominating CA research, with arguably limited and potentially biased research agendas (Wood, Dougill, Quinn, \& Stringer, 2016). As evidence from independent local research is sparse, key policy documents are disproportionately informed by evidence generated by NGOs with funding from international donor agencies. For instance, the CA guidelines for Malawi, endorsed and adopted by the national conservation agriculture task force (NCATF) and the MoAIWD, are a mirror image of Total Land Care's CA implementation guidelines and approach (see Total Land Care [TLC], 2015 and NCATF, 2016). Overreliance on NGOs' evidence, which is primarily generated to serve international donor interests (Escobar, 1995), potentially undermines stakeholder consensus in development of a robust and widely acceptable national CA policy.

Without highlighting CA research in the NAP and ASWAp, resource mobilisation for local CA research becomes challenging; since the government's research agenda emphasises development of new varieties that are drought tolerant, disease resistant and high yielding in response to challenges of declining agricultural productivity and weather-related risks (Malawi Government, 2016). However, the literature widely acknowledges the need for more research to adapt and contextualise CA to achieve sustained adoption (Twomlow \& Delve, 2016; Baudron, Thierfelder, Nyagumbo, \& Gerard, 2015; Andersson \& D'Souza, 2014). In the Malawi CA guidelines, a narrow research agenda, focused on biophysical and economic analyses to support the efficacy of CA, has overlooked the important role of participatory and interdisciplinary social and political-institutional aspects of CA, which are crucial for sustaining adoption among smallholder farmers (Friedrich, Kassam, \& Taher, 2009). Lack of a robust CA research programme has led to paucity of local evidence pertaining to social, political, and institutional features which shape the environment and experiences of farmers implementing CA.

This article reveals that insufficient CA integration in agricultural policies contributes to incoherencies of agricultural department policies. For instance, while the DLRC is the lead department for promoting CA, collaborative linkages with other departments are not well defined, therefore CA is not broadly embedded in other departmental strategies. As a result, the strategies are not well synchronised for coherence with CA, leading to conflicts with CA (Table 4). While the Crops Department is rationally mandated to modernise and mechanise agriculture by promoting tractor-drawn or oxen-drawn ploughs, cultivators and ridgers, exclusion of specialised CA equipment puts the strategy in conflict with CA's minimum soil disturbance principle, which discourages ploughing or ridging (Derpsch, Friedrich, Kassam, \& Hongwen, 2010; African Conservation Tillage Network, 2016). Similarly, promotion of residue incorporation by the DLRC and DAHLD's crop residue livestock strategies have negative impacts on CA's pillar of continuous soil cover, as they limit availability of mulch materials in smallholder communities and thus negatively affect CA adoption. While concurring with Cejudo and Michel (2017) in observing interconnectedness of policy integration and coherence, this study emphasises that stronger CA integration into agricultural policies, coupled with strong collaboration among relevant stakeholders, is necessary to improve the policy environment in which smallholders operate. This may facilitate sustained implementation of CA leading to durable impacts of agricultural innovations more broadly.

Though aimed at being the handbook for CA implementation, the CA guidelines contain inconsistencies and controversies capable of undermining CA. Notably, despite calling for flexibility in CA dissemination to adapt $\mathrm{CA}$ to local contexts, the CA guidelines demonstrate rigidities in dissemination approaches exemplified by declaring that no-till system is 'non-negotiable' (NCATF, 2016; TLC, 2015). Rigidity in CA projects may fuel farmers' perceptions of being 'forced' to adopt CA configurations pre-determined by promoters as reported in the literature, disregarding local needs and aspirations, thereby jeopardising local project ownership (Wood et al., 2016). In addition, rigid farming regimes are unable to effectively cope with current and future stresses therefore limit their adaptive capacity and growth (Dixon \& Stringer, 2015). Similarly, Dyer et al. (2014) emphasise flexibility and two-way communication as essential in CA project design. As "one size does not fit all" in project or programme design (Young, 2003 p390), Giller et al. (2015); Twomlow and Delve (2016) recommend a flexible CA package and a non-purist approach, to fit CA with farmers' unique situations and motivations for sustained adoption to occur. While the CA guidelines are meant to act as main tool for promoting CA, rigidities and inconsistent statements therein reinforce organisational practices that ignore farmers' aspirations, motivations and/or local context, which constrain adoption.

\section{Conclusion}

This article has examined CA integration and coherence of agricultural policies, and their possible implications for CA adoption. Findings indicate that integration of CA in the NAP is insufficient, and coherence of agricultural departmental strategies, in the context of CA in Malawi, is lacking. These policy deficiencies are mainly propelled by narrow focus of CA in the sectoral policies; weak political support for CA; poor sub-sectoral collaboration and coordination; poor knowledge-exchange in planning and implementation; and un-harmonised 
departmental strategies. Deficient CA integration and lack of coherence for CA in agricultural department strategies engender institutional constraints which potentially impinge adoption. These findings show that there is need to strengthen multidisciplinary research and engagement with policy makers and processes and raise awareness of the potential of CA, with a view to enhancing CA integration in relevant national policy objectives. Improved collaboration among relevant agricultural stakeholders is needed to enhance CA-coherence of agricultural strategies. This could be achieved through the new National Agricultural Investment Plan and National Resilience Strategy being developed, which present opportunities for greater coherence in policy planning in Malawi.

Our article makes an important contribution to a body of literature on agriculture and sustainability in sub-Saharan Africa through critical policy analysis to demonstrate how policies at national level may influence adoption of agricultural innovations at the grassroots. By analysing the extent of integration of CA and coherence of policies, the article has unveiled policy narratives capable of undermining adoption. The study provides empirically grounded knowledge vital for improved decision-making and project design of agricultural interventions, applicable to similar situations in sub-Saharan Africa. This knowledge may facilitate shifts in farming system practices towards sustainable agricultural development in the region.

\section{Acknowledgements}

This study was funded by the Commonwealth Scholarship Commission.

\section{References}

African Conservation Tillage Network. (2016). International Conservation Agriculture advisory panel for Africa (ICAAP-Africa). Nairobi: African Conservation Tillage Network (ACT).

Andersson, J. A., \& D'Souza, S. (2014). From adoption claims to understanding farmers and contexts: A literature review of conservation agriculture (CA) adoption among smallholder farmers in Southern Africa. Agriculture, Ecosystems and Environment, 187, 116-132. https://doi.org/10.1016/j.agee.2013.08.008

Atela, J., Quinn, C. H., Minang, P. A., Duguma, L. A., \& Houdet, J. A. (2016). Implementing REDD+ at the national level: Stakeholder engagement and policy coherences between REDD+ rules and Kenya's sectoral policies. Forest Policy and Economics, 65, 37-46. https://doi.org/10.1016/j.forpol.2016.01.003

Baudron, F., Thierfelder, C., Nyagumbo, I., \& Gerard, B. (2015). Where to Target Conservation Agriculture for African Smallholders: How to Overcome Challenges Associated with its Implementation? Experience from Eastern and Southern Africa. Environments, (2), 338-357. https://doi.org/10.3390/environments2030338

Baudron, F., Andersson, J., Corbeels, M., \& Giller, K. (2011). Failing to Yield? Ploughs, Conservation Agriculture and the Problem of Agricultural Intensification: An Example from the Zambezi Valley, Zimbabwe. Journal of Development Studies, 1(1), 1-28. https://doi.org/10.1080/00220388.2011.587509

Baxter, J., \& Eyles J. (1997). Evaluating Qualitative Research in Social Geography: Establishing Rigour in Interview Analysis. Trans Inst Br Geogr, 505-525. https://doi.org/10.1111/j.0020-2754.1997.00505.x

Bryman, A. (2016). Social research methods (5th edition). Oxford: Oxford University Press.

Cejudo, G., \& Michel, C. (2017). Addressing fragmented government action: Coordination, coherence, and integration. Policy Sciences, 50(4), 745-767. https://doi.org/10.1007/s11077-017-9281-5

Chandra, A., \& Idrisova, A. (2011). Convention on Biological Diversity: A Review of National Challenges and Opportunities for Implementation. Biodiversity and Conservation, 20(14), 3295-3316. https://doi.org/10.1007/s10531-011-0141-x

Chinseu, E. L. (2018). Smallholder farmers'dis-adoption of agricultural technologies: The case of conservation agriculture in Malawi ( $\mathrm{PhD}$ thesis, University of Leeds, Leeds, United Kingdom). Retrieved from http://etheses.whiterose.ac.uk/20773

Chinsinga, B., \& Chasukwa, M. (2015). Agriculture and climate change policy: Processes, decision makers and implementation instruments. Lilongwe: FAO.

Chinsinga, B. (2011). Seeds and subsidies: The Political Economy of Input Programmes in Malawi. IDS Bulletin, 42(4), 59-68.

Department of Irrigation Services. (2015). Semi-annual progress report. Lilongwe: Ministry of Agriculture, Irrigation and Water Development, Lilongwe Irrigation Services Division.

Derpsch, R., Friedrich, T., Kassam, A., \& Hongwen, L. (2010). Current Status of Adoption of No-till Farming in 
the World and Some of its Main Benefits. Int J Agric \& Biol Eng, 3(1), 1-26. https://doi.org/10.3965/j.issn.1934-6344.2010.01.001-025

Dixon, J., \& Stringer, L. (2015). Towards a Theoretical Grounding of Climate Resilience Assessments for Smallholder Farming Systems in sub-Saharan Africa. Resources, 4, 128-154. https://doi.org/10.3390/resources4010128

Doss, C. R. (2006). Analysing technology adoption using microstudies: limitations, challenges, and opportunities for improvement. Agricultural Economics, 34, 207-219. https://doi.org/ 10.1111/j.1574-0864.2006.00119.x

Dougill, A. J., Whitfield, S., Stringer, L. C., Vincent, K., Wood, B., Chinseu, E. L., ... Mkwambisi, D. D. (2017). Mainstreaming Conservation Agriculture in Malawi: Knowledge Gaps and Institutional Barriers. Journal of Environmental Management, 195, 25-34. https://doi.org/10.1016/j.jenvman.2016.09.076

Dyer, J., Stringer, L., Dougill, A., Leventon, J., Nshimbi, M., Chama, F., ... Syambungani, S. (2014). Assessing participatory practices in community-based natural resoures management: Experiences in community engagement from southern Africa. Journal of Environmental Management, 137, 137-145. https://doi.org/10.1016/j.jenvman.2013.11.057

England, M., A., Stringer, L., Dougill, A., \& Afionis, S. (2018). How do sectoral policies support climate compatible development? An empirical analysis focusing on southern Africa. Environmental Science and Policy, 79, 9-15. https://doi.org/10.1016/j.envsci.2017.10.009

Escobar, A. (1995). Encountering development: The making and unmaking of the third world. Princeton: Princeton University Press.

FAO. (2015). Conservation Agriculture. Retrieved from http://fao.org/ag/ca/index.html

FAO. (2018). Climate smart agriculture: Natural resource management and policy. https://doi.org/10.1007/978-3-319-61194-5.

FAO, IFAD, UNICEF, WFP and WHO. (2017). The State of food security and nutrition in the World 2017. Building resilience for peace and food security. Rome: FAO.

Feder, G., Just, R. E., \& Zilberman, D. (1985). Adoption of agricultural innovations in developing countries: A survey. Economic Development and Cultural Change, 33(2), 255-297. https://doi.org/10.1086/451461

Friedrich, T., \& Kassam, A. (2009). Adoption of Conservation Agriculture Technologies: Constraints and Opportunities. New Dehli: IVth World Congress on Conservation Agriculture.

Friedrich, T., Kassam, A., \& Taher, F. (2009). Adoption of Conservation Agriculture and the Role of Policy and Institutional Support. Paper Presented at the International Consultation on No-Till with Soil Cover and Crop Rotation. Kazakhstan, 8-10 July, 2009. Kazakhstan: FAO.

Giller, K., Andersson, J., Corbeels, M., Kirkegaard, J., Mortensen, D., Erenstein, O., \& Vanlauwe, B. (2015). Beyond Conservation Agriculture. Frontiers in Plant Science, 6. https://doi.org/10.3389/fpls.2015.00870

Glasbergen, P. (1996). Learning to Manage the Environment. In W. Lafferty, \& J. Meadowcroft, Democracy and the Environment Problems and Prospects (pp. 175-193). Cheltenham: Edward Elgar.

Glover, D., Sumberg, J., \& Andersson, J. (2016). The adoption problem: or why why we still understand so little about technological change in African agriculture. Outlook on Agriculture, 45(1), 3-6. https://doi.org/10.5367/oa.2016.0235

Gomar, J., Stringer, L., \& Paavola, J. (2014). Regime Complexes and National Policy Coherence: Experiences in the Biodiversity Cluster. Global Governance, 20, 119-145. https://doi.org/10.5555/1075-2846-20.1.119

Gondwe, T. (2015). Crop livestock integration potentials and priorities for mixed farming systems in Northern Malawi: Agriculture responses to climate change. 3rd Biennial Conservation Agriculture and 1st Climate Smart Agriculture Symposium (26-28 May, 2015). Lilongwe.

Hall, A., Mytelka, L., \& Oyeyinka, B. (2006). Concepts and guidelines for diagnostic assessments of agricultural innovation capacity. Working paper series \#2006-017. Maastricht: United Nations University UNU Merit.

Hay, I. (2010). Qualitative research methods in human geography. Oxford: Oxford University Press.

Kalaba, F., Quinn, C., \& Dougill, A. (2014). Policy Coherence and Interplay Between Zambia's Forest, Energy, Agricultural and Climate change Policies and Multilateral Environmental Agreements. International Environment Agreements: Politics, Law and Economics, 13(4). https://doi.org/10.1007/s10784-013-9236-z 
Kaluzi, L., Thierfelder, C., \& Hopkins, D. W. (2017). Smalholder farmer innovations and contexts in maize-based conservation agriculture systems in Central Malawi. Sustainable Agriculture Research, 6(3), 85-105. https://doi.org/10.5539/sar.v6n3p85

Kirkegaard, J., Conyers, M., Hunt, J. Kirkby, C., Watt, M., \& Rebetzke, G. (2014). Sense and nonsense in conservation agriculture: Principles, pragmatism and productivity in Australian mixed farming systems. Agriculture, Ecosystems and Environment, 187, 133-145. https://doi.org/10.1016/j.agee.2013.08.011

Lasco, R., Cruz, R., Pulhin, J., \& Puhlin, F. (2006). Tradeoff analysis of adaptation strategies for natural resources, water, resources and local institutions in the Phillipines. AIACC Working paper. Washington DC: AIACC.

Lipper, L.,Thornton, P., Campbell, B., Baedeker, T., Braimoh, A., Bwalya, M., ... Torquebiau, E.F. (2014). Climate-smart agriculture for food security. Nature Climate Change, 4, 1068-1072. https://doi.org/10.1038/NCLIMATE2437

Malawi Government. (2010). The Agriculture Sector Wide Approach (ASWAp): Malawi's prioritised and harmonised agricultural development agenda. Lilongwe: Ministry of Agriculture and Food Security.

Malawi Government. (2012). Guide to agricultural production and natural resources management. Lilongwe: Ministry of Agriculture and Food Security.

Malawi Government. (2016). National agriculture policy. Lilongwe: Ministry of Agriculture, Irrigation and Water Development.

May, P.J., Sapotichne, J., \& Workman, S. (2006). Policy coherence and policy domains. Policy Studies Journal, 34(3), 381-403. https://doi.org/10.1111/j.1541-0072.2006.00178.x

Mereu, V., Santini, M., Cervigni, R., Augeard, B., Bosello, F., Scoccimarro, E., ... Valentini, R. (2018). Robust Decision Making for a ClimateResilient Development of the Agricultural Sector in Nigeria. In L. Lipper, N. McCarthy, D. Zilberman, S. Asfaw, \& G. Branca, Climate Smart Agriculture, Natural Resource Management and Policy. https://doi.org/10.1007/978-3-319-61194-5_13

Mloza-Banda, H. R., \& Nanthambwe, S. (2010). Conservation agriculture programs and projects in Malawi: Impacts and lessons. A technical report submitted for the National Conservation Agriculture Task Force Secretariat. Lilongwe: Department of Land Resources and Conservation.

Mwase, W., Jumbe, C., Gasc, F.,Owiyo, T., Manduwa, D., Nyaika, J., ... Maonga, B. (2014). Assessment of Agricultural Sector Policies and Climate Change in Malawi- The Nexus Between Climate Change Related Policies, Research and Practice. Journal of Sustainable Development, 7(6), 195-203. https://doi.org/10.5539/jsd.v7n6p195

Nanthambwe, S., \& Mulenga, N. (1999). An account of the history of soil and water conservation related agricultural extension in Malawi. Lilongwe: Department of Land Resources Conservation, Ministry of Agriculture and Food Security.

National Conservation Agriculture Task Force (NCATF). (2016). Guidelines for implementing conservation agriculture in Malawi. Lilongwe: NCATF.

Nilsson, M., Zamparuti, T., Petersen, J., Nykvist, B. Rudberg, P., \& McGuinn, J. (2012). Understanding Policy Coherence: Analytical Framework and Examples of Sector-Environment Policy Interactions in the EU. Environment Policy and Governance, 22, 395-423. https://doi.org/10.1002/eet.1589

Njira, K., \& Nabwami, J. (2013). Soil Management Practices that improve Soil Health: Elucidating their Implications on Biological Indicators. Animal and Plant Sciences, 18(2), 2750-2760. Retrived from http://www.m.elewa.org/JAPS

Oberthur, S. (2009). Interplay management: enhancing environmental policy integration among international institutions. Int Environ Agreements, 9, 371-391. https://doi.org/10.1007/s10784-009-9109-7

Oberthur, S., \& Gehring, T. (2006). Institutional interaction in global environmental governance. Cambridge, MA: The MIT Press.

Rainwater Harvesting Association of Malawi (RHAM). (2013). Initiatives and highlights of the Rainwater Harvesting Association of Malawi. Lilongwe: RHAM.

Sasakawa Africa Association. (2007). Sasakawa Global 2000 Malawi report. Lilongwe: Sasakawa Africa Association. 
Scott, J. (1990). A matter of record: Documentary sources in social research. Cambridge: Polity Press.

Soderberg, C. (2008). Much Ado about Nothing?-Energy Forest Cultivation in Sweden: How Intersectoral Policy Coordination Affects Outcomes from EPI in Multisectoral Issues. Journal of Environmental Policy and Planning, 10(4), 381-403. https://doi.org/10.1080/15239080802332042

Spielman, J., \& Birner, R. (2008). How innovative is your agriculture? Using innovation indicators and benchmarks to strengthen national agricultural innovation systems. Washington: World Bank.

Steward, P. R., Dougill, A. J., Thierfelder, C., Pittelkow, C. M., Stringer, L. C., Kudzula, M., \& Shackleford, G. E. (2018). The adaptive capacity of maize-based conservation agriculture systems to climate stress in tropical and subtropical environments: A meta-regression of yields. Agriculture, Ecosystems and Environment, 251(1), 194-202. http://doi.org/10.1016/j.agee.2017.09.019

Stringer, L., Dougill, A., Thomas, A., Stracklen, D., Chesterman, S., Chinwe, I., ... Kopolo, G. (2012). Challenges and Opportunities in linking carbon sequestration, livelihoods and ecosystem service provision in drylands. Environmental Science and Policy, 19-20, 121-135. https://doi.org/10.1016/j.envsci.2012.02.004

Stringer, L., Dyer, J., Reed, M., Dougill,A., Twyman, C., \& Mkwambisi, D. (2009). Adaptations to Climate Change, Drought and Desertification: Local Insights to Enhance Policy in Southern Africa. Environ. Sci. Policy. https://doi.org/10.1016/j.envsci.2009.04.002, 1-18.

Sutcliffe, C., Dougill, A., \& Quinn, C. (2016). Evidence and perceptions of rainfall change in Malawi: Do maize cultivar choices enhance climate change adaptation in sub-Saharan Africa? Reg Environ Change, 16, 1215-1224. https://doi.org/10.1007/s10113-015-0842-x

Teklewold, H., Kassie, M., \& Shiferaw, B. (2012). Adoption of multiple sustainable agricultural practices in rural Ethiopia. Sweden: University of Gothenburg.

Thierfelder, C., Matemba-Musasa, R., Bunderson, T., Mutenje, M., Nyagumbo, I., \& Mupangwa, W. (2016). Evaluating manual conservation agriculture systems in southern Africa. Agriculture, Ecosystems and Environment, 222, 112-124. https://doi.org/10.1016/j.agee.2016.02.009

Total Land Care (TLC). (2015). Conservation agriculture in East and Southern Africa: Evidence and guidelines for implementation. TLC Booklet No. 4. Lilongwe: Total Land Care.

Twomlow, S., \& Delve, R. (2016). Lessons learnt: Designing and implementing conservation agriculture in sub-Saharan Africa. Rome: IFAD.

Waitt, G. (2010). Doing Foucaldian discourse analysis: Revealing social realities. In I. Hay, Qualitative research methods in human geography (pp. 217-240). Oxford: Oxford University Press.

Whitfield, S., Dougill, A., Dyer, J., Kalaba, F. Leventon, J., \& Stringer, L. (2015). Critical Reflection on Knowledge and Narratives of Conservation Agriculture in Zambia. Geoforum, 60, 133-142. https://doi.org/10.1016/j.geoforum.2015.01.016

Wood, B., Dougill, A., Quinn, C., \& Stringer, L. (2016). Exploring power and procedural justice within Climate-Compatible Development project design: Whose priorities are being considered? Journal of Environment and Development, 25(4), 363-395. https://doi.org/10.1177/1070496516664179

Young, O. (2003). Environmental Governance: The Role of Institutions in Causing and Confronting Environmental Problems. International Environmental Agreements: Politics, Law and Economics, 3, 377-393. https:doi.org/10.1023/B:INEA.0000005802.86439.39

Young, O. R. (2002). The institutional dimensions of environmental change: Fit, interplay and scale. Cambridge, MA: The MIT Press.

\section{Copyrights}

Copyright for this article is retained by the author(s), with first publication rights granted to the journal.

This is an open-access article distributed under the terms and conditions of the Creative Commons Attribution license (http://creativecommons.org/licenses/by/3.0/). 